\title{
塩基-塩化マグネシウム系によって促進される二酸化炭素 による活性メチレン化合物のカルボキシル化
}

\section{1 粕霉}

(1976 年 8 月 9 日受理)

松村昇・八久義雄・井本英二* は $78 \%$ となる。 みが得られる。 構は目下検討中である。
1,8-ジフザビシクロ[5.4.0]ウンデクー7-エン（以下 DBU と略 記する）は DMF 中，二酸化笼菜加压下，あるいは常压下で活性 メキレン化合物をカルポキシル化する12)。しかし，DBU よりる 塩基性の彁いトリエチルフミンやトリェキレンジアミンを用いる と活性メチレン化合物のカルボキシル化は起こらない。さて，ビ オチン含有酵素は $\mathrm{Mg}^{2+}$ のよらな2 価金属イオンが ATP およ び $\mathrm{NaHCO}_{3}$ と共存するときのみアシル $\mathrm{CoA}$ をカルボキシル化 ナる。また著者らはビオチンモデル反応関する一連の研究の中 で, 2-オキソイミダゾリン-1-カルボン酸メテルのメトキシカル ボニル基の求電子性は $\mathrm{Mg}^{2+}$ イオンによって增強されることを見 いだしているす。

著者らはこの雨事実を参都にして，トリエチルアミン (TEA) またはトリエチレンジフミン (TED) に塩化マグネシウムを加六， 活性メキレン化合物の二酸化炭素によるカルボキシル化を行なっ たところ，好収率でカルボキシル化が起こることを諗めた。この 結果をここに報告する。

\section{2 蛣果と考察}

カルボキシル化反応の結果（表 1)を要約するとつぎのようにな る。

(1) TEA または TED に $\mathrm{MgCl}_{2}$ を添加するとインデンか らインデンー3-カルボン酸 [1]が好収率で得られる。しかし $\mathrm{MgCl}_{\mathrm{g}}$ を添加しないときは，表 1 に示していないがカルボキシル化物は 得られない。

(2) TED- $\mathrm{MgCl}_{2}$ を用い, インデンをカルボキシル化すると き，TED， $\mathrm{MgCl}_{2}$ ，インデンの最的関係によって[1]の取率は図 1に录すよらに変化する。

(a) $\mathrm{MgCl}_{2}$ /Indene のモル比が 1 のとき, $\mathrm{TED} / \mathrm{MgCl}_{2}$ のモ ル比が 2 以下であれば〔1]は浪とんど得られない。しかし， を越光ると急に〔1]の収率は増大する。

(b) $\mathrm{MgCl}_{2}$ /Indene のモル比が 1 のとき, $\mathrm{TED} / \mathrm{MgCl}_{2}$ のモ ル比 2 以上に大きくしても〔1]の収率は 50\%を越えない。 しかし， $\mathrm{MgCl}_{2} /$ Indene のモル比が 2 のとき，表1に記したよう

* 大阪府立大学工学部応用化学教室, 591 摆市百舌鳥梅町

1）春木英一，荒川宗和，沢田覀三，井本英二，日本化学会第 32 春季年会講演予稿集, III, p.1836(1975).

2) E. Haruki, M. Arakawa, N. Matsumura, Y. Otsuji, E. Imoto, Chem. Lett., 1974, 427.

3）松村 昇, 河合 博, 春木英一，大止吉男，玤本英二，日

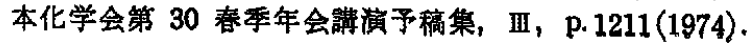

にたとえば TED/ $\mathrm{MgCl}_{2}$ のモル比が3であれば，〔1〕の収率

（3）厡素誘導体のリチウム塩")，DBU2）を用いるインデンの カルボキシル化反底では，ジカルボキシル化物またはモノおよび ジカルボキシル化物の混合物が得られるが，TEA または TED と $\mathrm{MgCl}_{2}$ を用いる場合は選択的にモノカルボキシル化物 [1]の

（4）TEA または TED に $\mathrm{MgCl}_{2}$ を添加した場合，インデ ンと同様にフルオンン，アセトフェノン，チオ釄酸 Sーペンジル す同様にカルボキシル化されそれれれれフルオレンー9-カルボン 酸, ベンゾイル酢酸, ベンジルチオカルボニル酿酸を生成する。 な⿰幺上のカルボキシル化に括ける塩化マグネシウムの作用機

\section{3 实誤}

耐圧ガラス管に，脱水剂としてモレキュラシーブ $4 \mathrm{~A} \mathrm{1/16} \mathrm{2g，}$ 無水塩化 $マ$ グネシウム $(9.08 \mathrm{mmol})$, 活性メチレン化合物 (4.54 $\mathrm{mmol})$, トリエチレンジアン(またはトリニチルフミン) (27.24 $\mathrm{mmol})$ および DMF $10 \mathrm{ml}$ をとり，約 20 分間かきまぜ塩化マグ ネシウムを溶解した。その後，二酸化岸妻で管内を十分贯换した のち、二酸化炭素代を $5 \mathrm{~kg} / \mathrm{cm}^{2}$ に調整した。するとたたちたに DMF 溶液は高粘度となった。しかし室温で, 加圧, かきまぜを 17 時間つつけたのちは低粘度に変わった。反底終了後，反底溶 液を隶水に移し，エーテルで抽出し，エーテル畨から未反応の活 性メチレン化合物を回收した。水層は冷却下灌塩酸で酸性とした

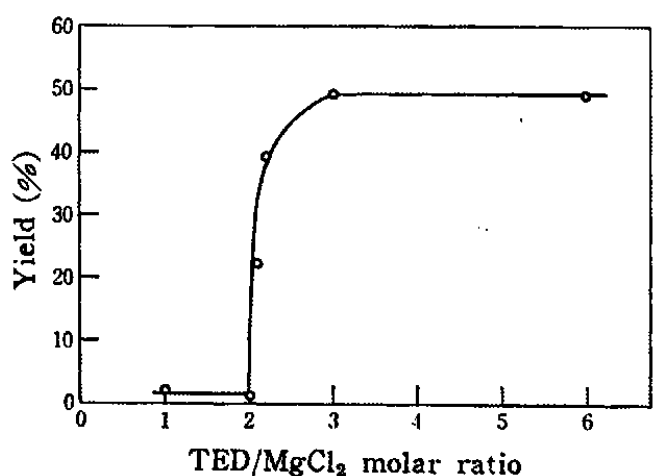

Fig. 1 Yield of indene-3-carboxylic acid [1] in the carboxylation of indene with $\mathrm{TED}-\mathrm{MgCl}_{2}$ when the molar ratio of $\mathrm{MgCl}_{2} /$ Indene is 1

4) Y. Otsuji, M. Arakawa, N. Matsumura, E. Haruki, Chem. Lett., 1973, 1193. 
Table 1 Carboxylation of active methylene compounds with TED (or TEA)*$\mathrm{MgCl}_{2}-\mathrm{CO}_{2}$ system $^{\alpha}$ )

\begin{tabular}{lccccc}
$\begin{array}{c}\text { Active methylene } \\
\text { compound (mmol) }\end{array}$ & Base (mmol) & $\begin{array}{c}\mathrm{MgCl}_{2} \\
(\mathrm{mmol})\end{array}$ & $\begin{array}{c}\text { Time } \\
(\mathrm{hr})\end{array}$ & Product & $\begin{array}{c}\text { Yield of } \\
\text { product }(\%)\end{array}$ \\
\hline Indene (4.54) & TED (9.08) & 4.54 & 17 & Indene-3-carboxylic acid & 0.7 \\
& TED (9.53) & 4.54 & 17 & & 22 \\
& TED (9.99) & 4.54 & 17 & & 39 \\
& TED (13.62) & 4.54 & 17 & & 49 \\
& TED (27.24) & 4.54 & 17 & & 49 \\
& TED (27.24) & 9.08 & 17 & & 78 \\
Acetophenone (4.54) & TEA (27.24) & 9.08 & 17 & & 79 \\
Fluorene (4.54) & TED (27.24) & 9.08 & 17 & Benzoylacetic acid & 74 \\
S-Benzyl thioacetate & TEA (27.24) & 9.08 & 17 & & 76 \\
(4.54) & TEA (27.24) & 9.08 & 72 & (Benzylthio) carbonylacetic acid & 40
\end{tabular}

* $\mathrm{TED}=$ Triethylenediamine, TEA = Triethylamine.

a) The reaction was carried out at room temperature under the pressure of carbon dioxide $5 \mathrm{~kg} / \mathrm{cm}^{2}$ in $10 \mathrm{~m} l$ of DMF.

のら、ェーテルで抽出し，そのェーテル周を冷水で水洗， $\mathrm{MgSO}$ 、 で暲燥したのち、エーテルを留去して活性メキレン化合物のそノ カルボン酸を得た。インデンー3-カルボン酸ら， ベンソ゚イル酢酸”， フルオレン-9-カルボン酸》の確認は融点, IR, NMR, MS スベ トルの文献值との比較および元素分析により行なったのベンジル

5) A. Melera, M. Claesen, H. Vanderhaeghe, J. Org, Chem., 29, 3705(1964).

6) M.Stiles, J. Am. Chem. Soc., 81, 2598(1959).

7) A. Jeanes, R. Adams, ibid., 59, 2608(1937).

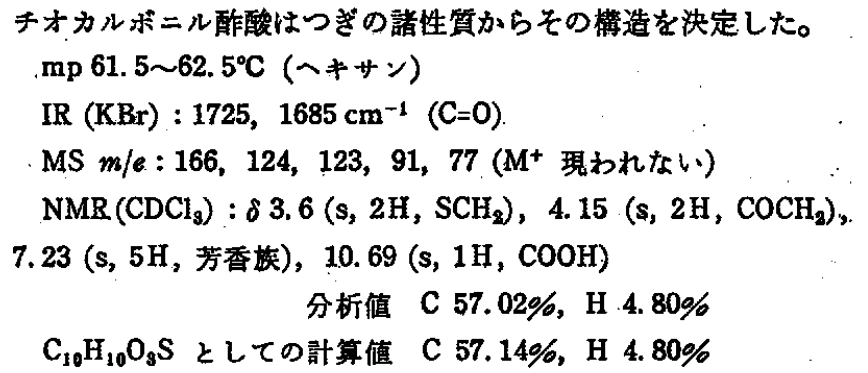

キオカルボニル酭酸はつぎの諸性筫からその棈造を決定した。 $\mathrm{mp} 61.5 \sim 62.5^{\circ} \mathrm{C}$ (ヘキサン)

IR (KBr) : 1725, $1685 \mathrm{~cm}^{-1}(\mathrm{C}=0)$

MS $m / e: 166,124,123,91,77$ ( $\mathrm{M}^{+}$現われない)

$\mathrm{NMR}\left(\mathrm{CDCl}_{3}\right): \delta 3.6\left(\mathrm{~s}, 2 \mathrm{H}, \mathrm{SCH}_{2}\right), 4.15\left(\mathrm{~s}, 2 \mathrm{H}, \mathrm{COCH}_{2}\right)$,

$\mathrm{C}_{10} \mathrm{H}_{10} \mathrm{O}_{3} \mathrm{~S}$ としての計算値 C $57.14 \%, \mathrm{H} 4.80 \%$

\section{Carboxylation of Active Methylene Compounds with Carbon Dioxide Promoted by the Base- $\mathrm{MgCl}_{2}$ System}

Noboru Matsumura, Yoshio Yagyu and Eiji Imoto Department of Applied Chemistry, College of Engineering, University of Osaka Prefecture; Sakai-shi 591 Japan

The binary systems consisting of triethylenediamine or triethylamine and $\mathrm{Mg}$ (II) salt promote the carboxylation of active methylene compounds with carbon dioxide. Only monocarboxylic acids derived from the active methylene compounds are obtained in a good yield. 